\title{
Individual Creativity and the Influence of Mindful Leaders on Enterprise Innovation
}

\author{
R. Ray Gehani'
}

\begin{abstract}
Creativity and innovation drive competitiveness in the 2 lst century enterprises. Dynamic hyper-intensive competitive markets demand widespread innovations from all employees in most global enterprises. Leaders influence and set the contextual environments under which their employees express creativity. This paper will examine how different leadership models relate with individual creativity. It is noted that the mindful consciousness of individuals, including their leaders, play significant roles in the individuals' creativity. This exploratory research study first defines creativity and individual creativity, and then examines the five different orientations of leaders' influences on the individuals' creativity. In conclusion, selected managerial and educational implications are suggested.
\end{abstract}

Keywords: Creativity; individual creativity; leadership; mindful; innovation; technology management; strategic advantage.

' Director, Graduate Programs in Technology Management and Innovation, The University of Akron, College of Business \#358, 259 South Broadway, Akron, Ohio 44308. (330) 972-8I40. Email: rgehani@uakron.edu 


\section{Individual Creativity for Competitive Advantage}

How can global enterprises leverage creativity to sustain their competitiveness in the 2 lst century economies? Radical technological innovations disrupt market dynamics and change the rules of global competition (Gehani, 1998). Launch of creative radical innovations, such as the recent launches of Google search engine, Apple iPhone, and Facebook social media, disrupt market dynamics significantly (Gehani, 2010). These creative strategies of new entrants not only change the rivalry and intensity of the market competition, but they also change the ground-rules of the competitive game in the industry. Old ways of conducting business and competing cease to be advantageous. Creative innovative approaches are needed by leaders to either match such emerging environmental shifts, or to proactively stay ahead of their innovating rivals.

Dynamic changes in an organization's environment demand creative solutions and innovative responses. Such innovative responses rely heavily on the creative performance of individual employees. What are the factors that significantly influence creativity related behaviors in individuals? A key driver of an individual employee's creative performance is the influence of leaders. Particularly, consciousness and mindfulness of individuals and leaders make big difference in the individuals' creativity. Whereas a number of researchers have focused on development of group creativity and enterprise creativity (Amabile and Khaire, 2008; Amabile, 1997; Arendt, 2009; Csiksentmihaly, 1990), relatively much less research has been done on individual creativity. This exploratory research study attempts to fill that crucial gap in our collective understanding.

\section{A. Influence of Leaders on Individual Creativity}

Creativity is the capability to create something novel, unique, and value-adding. Whereas it has always driven most enterprises, creativity has not been the most important or the most urgent item on the agenda for change by many American leaders in the upper echelons of leading enterprises (Amabile, 2008). Many well-known enterprises, such as Apple, Microsoft, Google, and more, were born out of the creative entrepreneurial efforts of their founderleaders. But as such organizations grow and achieve a viable size, nurturing of creativity often takes a secondary role. Some newly appointed successor leaders consider creativity as something too hard to manage. Or they fear that the outcomes of creativity have a long lag time beyond their own tenure and time horizon in an enterprise. Some of them believe that the efforts and resources they invest in improving the creativity of their individuals and their enterprises would not produce results while they are still leading that enterprise. They, therefore, get too busy running the day to day operations, thereby neglecting the long-term futures of their enterprises.

Innovative enterprises (such as Google), expect creative ideas to emerge from their employees and leaders at all levels. Unfortunately, developing the creative mindsets of different individuals has been often neglected by many enterprises (Amabile and Khaire, 2008). Whereas fostering a corporate culture for creativity may produce some low lying fruits, nurturing creative minds is America's core challenge for gaining a sustained global competitiveness.

\section{Four-Step Framework of This Research Study}

The research study follows a logical four-step sequence. First, creativity in general and individual creativity in particular, is defined clearly in this study. Three key elements of individual creativity are discussed. These are: (A) cognitive abilities of individuals, (B) mastery of a discipline, and $(C)$ subjectivity of creative output and performance. Second, the evolving models of leaders and their influence on individual creativity are reviewed. Particularly, the evolution of servant leaders into mindful creative leaders is proposed. Third, five different levels of leaders' influences on individuals' creativity are discussed in the context of the influence of more mindful leaders. And fourth, selected managerial and educational implications of this research study are suggested.

\section{Defining Creativity in Individuals}

Creative behaviors are easy to recognize but hard to define precisely. A creative product, service, or work of art is something that is novel and useful. It may be useful and novel either to the individual or to the society as a whole. Creativity with personal novelty is more common than creativity that is novel society-wide - that is something that has been never before experienced or produced by a society. Creativity may range from the mundane to extraordinary (Smith et al., 2000). 
Creative individuals generate ideas and products that are relatively novel, adaptive, and useful (Csikszentmihalyi, 1994, 1996; Sternberg and Lubart, 1995). Creative individuals induce a change in a domain over time. Charles Darwin innovated the way human development was perceived. Spanish painter Picasso created a new cubist perspective in the domain of painting.

Brown (1989) and other researchers have identified four P components of creativity. These are: (I) personal characteristics, (2) processes, such as thought processes, (3) products, services, and outcomes produced, and (4) the presence of contextual environment.

\section{Three Key Components of Individual Creativity}

In general, creativity distinguishes humans from other animals. Each one of us has within us the cumulative genetic code of our Mother Nature's creativity since the Big Bang. But all individuals are not equally effective in being purposefully creative.

Some of the commonly understood indicators of a creative individual are: (I) cognitive abilities including general intelligence, (2) mastery of a discipline, and (3) thesubjectivity of their actual creative output such as performance on creativity tests involving puzzle-solving ability.

\section{Creative Thinking Personality and Cognitive Abilities}

Whereas high expertise in a discipline is necessary for a creative individual, this is not sufficient to produce creative performance. Creative thinking personality includes the skills listed below (Golann, 1963; Amabile, 1983; 1996).

(a) High tolerance for ambiguity,

(b) Self-dependence and independence,

(c) Lack of concern for social approval,

(d) Persistent pursuit of a challenge,

(e) Risk-taking and,

(f) An exploratory cognitive style or heuristics to seek new perspectives on a problem.

Learning and experience can improve an individual's creative thinking. A number of specific cognitive abilities have been measured as associated with individual creativity. Guilford (1968) noted divergent thinking, or a capacity to flexibly generate a variety and a large number (fluency) of ideas. Vincent at al. (2002) noted that divergent thinking had a significant effect on creative problem solving that was not attributable to expertise or intelligence.

Creative problem solving demands generation of new knowledge, and a systematic integration of extant schema or categorical information structures (Mumford and Gustafson, 200I). These researchers and others such as Amabile (1996) and Weisberg (1999) emphasize the significance of domain-specific knowledge in the creative problem-solving processes.

Some researchers, such as Getzels (1975) differentiate problem finding as different from problem solving in creativity. Problem finding involves a cognitive capacity to reframe or redefine a problem creatively. Problem finding often demands more creative insights than problem solving. Creative individuals have been empirically found to have superior problem finding skills (Getzels and Csikszentmihalyi, 1976; Runco and Sakamoto, 1999).

\section{Mastery of a Domain-specific Discipline}

Expertise or mastery of a discipline as a measure of creativity relies on the assumption that creativity is domain specific. In other words, creative individuals are creative only within a discipline, and only after many years of detailed study (Gardner, 1993). Expertise provides the cognitive pathways to creatively solve certain problems. Newell and Simon (1972) proposed that expertise provides a network of possible wanderings to a creative problem solver. Expertise includes special talents in the target work domain, technical proficiency, and memory for factual knowledge (Amabile, 1997).

For example, Charles Darwin invested many decades studying scientific literature, traveling to the isolated Galapagos islands, making detailed observations, and writing thousands of pages of notes before he created and presented his theory of evolution to the world. Alfred Kinsey (1894-1956) of Indiana University at Bloomington painstakingly collected and classified almost a million gall wasps, and took thousands of interviews of American men and women to create his theories of Sexual Behavior in the Human Male (1948) and Sexual Behavior in the Human Female (1953) in America. 
Creative leaders in many organizations try to become a subject matter expert on a key aspect of strategic importance to their enterprises. They become the "go-togal or guy" on that subject. This helps build their credibility in others. Their areas of expertise may vary. Some gain high-level fluency in the foreign language of an important region of their global markets. Others build expertise in a functional area such as information technology, social media advertising, or supplier sourcing.

According to Marc Hofer, CEO of Simpler Consulting, a global lean management consulting firm, "It is usually the subject matter expertise that gets managers promoted (into leaders), not their leadership expertise. (Most) companies don't invest in that kind of development. Even if they had the inclination, they wouldn't quite know where to start in some cases" (Minter, 20II).

\section{Subjectivity of Creative Output and Courage}

Unfortunately, actual creative output is often perceived as subjective and situational. Perception of creativity varies from person to person. Some of the leading scientists contemporary to Einstein, such as Planck, Mach, Poincare, and Lorentz, mostly ignored Einstein's special theory of relativity (Gardner, 1993). Picasso's Les demoiselle's d'Avignon, considered a radical creative step to cubism art, was adversely criticized by leading observers of his time (Gardner, 1993).

A creative individual, therefore, must develop a lot of courage to stand-up and claim to be different. Galileo promoted and demonstrated a new evidence-based view of our world. The church elders in his community, believing that earth was at the center of our universe, accused Galileo as heretic and blasphemous. Galileo, however, stood firm in his conviction. He secretly recorded his creative reflections, and smuggled these to his admiring students living outside Italy.

\section{Evolving Models of Leadership and Creativity}

Next, the different models of effective leadership evolving over times, and how leadership relates to individual creativity will be explored.

\section{Influence of Leaders on Individual Creativity}

Amabile (1996) examined creativity from the perspective of social psychology. Thus, she proposed that creativity in enterprises results from three person-specific components, and the social environment for the individual employees.

These person-specific components are as follows. First, domain-relevant skills and expertise include technical skills and task-based factual knowledge of the individual employees. Amabile (1997) proposed that expertise is the foundation for all creative work. Expertise provides a set of alternate cognition pathways, and a network of possible wanderings (Newell and Simon, 1972) to help creatively solve a problem. Next, creative thinking-related skills including appropriate cognitive style for generating new ideas, work style for creative performance, and personality traits of the individual such as independence and willingness to take risks are required to be developed. And third, internal task motivation of the individual was seen to affect the individuals' creativity.

In addition to these person-specific components of a leader, the social environment of the employees in an enterprise can either nurture or kill the individuals' creativity. Part of this social environment includes the individuals' leader who has a significant regulatory influence on motivating the individual employee (Amabile and Khaire, 2008).

Transformational leaders often behave in an extraordinary manner rather than in common ways. For example, Ted Turner strongly believed in a market demand for a $24 \times 7$ news channel, while the most established TV stations in the United States broadcasted news only during the prime time. When the parcel delivery companies, such as UPS, used a multi-tiered transportation and logistics network, Fred Smith, the founder of Federal Express, created a single tiered hub-and-spoke overnight delivery system (Gehani, 1998). Sir Richard Branson, the leader of the Virgin Group of industries, created more than 100 different innovative enterprises in a variety of diversified industries - contrary to the conventional popular wisdom. 
Arendt (2009) noted that transformational leaders use intellectual stimulation to encourage followers to use their imaginations. They challenge the status quo or the conventional ways of doing things and solving their problems. Furthermore, transformational leaders give individualized consideration to others. These mindful leadership practices encourage followers to take risks, and experiment with their exploratory ideas and approaches.

\section{Growing From Greenleaf's Servant Leader To Mindful Creative Leader}

Every year in America alone hundreds of books and thousands of articles are published on leadership (Jaworski, 1996). These books describe what well established leaders do, how they operate, and what organizations must mechanically do to develop such leaders. These books do not give as much credence to what the followers do or how they create.

From these mountains of books, Peter Senge, the innovative pioneer of organizational learning and the 1990 best-seller Fifth Discipline, strongly recommended Robert Greenleaf's 1977 best-selling book on Servant Leadership, because it provides deeper insights into the nature of the real leadership - grounded in a state of "being" rather than "doing." Greenleaf proposed that first and foremost, leaders must primarily choose to serve, as an expression of their being. Without willingness to serve mindfully, a leader's ability to lead others is severely limited. Serving is not just determined by the leaders' action but it is an expression of their being. Such willingness to serve is not limited to, or expected from, extraordinary transformational leaders like Mahatma Gandhi of India and the U.S. Civil Rights leader Rev. Martin Luther King Jr. This willingness to mindfully serve is an important part of all of us as self-leaders.

Hierarchical positional power that many leaders assert on their follower employees, on the other hand, has the potential to become corrupt quickly and easily. The formal power between the leader and the led creates a gap between them. This usually alienates the individuals from other leaders.

John Hamm, in his best-selling book, Unusually Excellent: The Necessary Nine Skills for the Practice of Great Leadership, stresses that,
"Real leadership equity is only earned, not bestowed. Just because you have been granted authority doesn't mean you're getting the full collaborative engagement of your employees. You may have their bodies and time 40 or 50 hours a week, but until you earn the privilege, from their point of view, you'll never have their hearts and minds."

In the 2 Ist century, most of the hierarchical institutions, from school systems to multinational enterprises (MNEs) and non-governmental organizations (NGOs) seem to be weakening. These are turning into less formal network organizations. In the summer of 201I, millions of people in the Middle Eastern states of Tunisia, Egypt, Yemen, Libya, Sudan and others revolted against the autocratic control of their hierarchical leaders who had been deeply entrenched into power for decades.

Joseph Jaworski's 1996 book on Synchronicity illuminates the nature of the mindful leaders' choices. According to Senge (1996), the Western enterprises and institutions consider leadership as a trait found in the selected few. This is based on a heroic psychology. Thus there is often a frantic search for the special hero-like individual with a rare leadership potential, rather than attempting to improve leadership potential of all individuals in an enterprise. In 2008, after the economic and political debacles caused by President George W. Bush's concerns for national security (in the aftermath of 9/II World Trade Center attacks), the majority of citizens of America elected the Democratic Party nominee Barak Obama as the new rescuing hero and the President of the struggling United States.

A lot of energy is usually spent on spotlighting every minor action that the selected heroic leader is doing or not doing. The selected leaders spend a lot of personal and enterprise time, money, and energy on maintaining their larger-than-life heroic leadership positions, while some of their followers are trying to wrestle the coveted position from that leader. When the situations turn bad, we squarely put blame on the selected and often selfanointed heroic leader - even though large parts of the results may be due to what that leader's predecessor started, or due to the uncontrollable but favorable shifts in external environment. When the situation seems desperate, we expect the next great heroic leader to rescue the passive and group of almost helpless followers, the enterprise, the university, or the nation. 
In all these efforts related to hero-like leadership, Senge (1996) points out, "...we totally miss the large question: What are we collectively able to create?" Our mindful consciousness can play a critical role in unleashing our abilities and willingness to create individually and collectively.

\section{Mindful Consciousness of Individuals and Leaders}

In the face of chaos and market turmoil, a mindfully creative leader is present in the moment, and therefore able to identify the fast-shifting and emerging new opportunities. A mindfully creative leader is usually fearless of failure, and is willing to take calculated risks. The mindfully creative leaders are optimistic and driven by hope, as they pursue self-fulfillment and self-actualization while developing their authentic core-competencies for the sake of benefits for their larger community. These core-competencies are value-adding, unique, and hard to imitate by others (Gehani, 1998). The mindfully creative leaders are usually not highly satisfied by merely imitating others. These creative leaders are not only connected to their inner Self, but they are also well-versed at connecting and collaborating with others with complimentary corecapabilities (Gehani, 20l la, 20llb, 20llc).

\section{Mindful Leaders' Influences on Individuals' Creativity}

Many leaders acknowledge that a majority of their employees want to perform well without a lot of dayto-day interference from leaders or unreasonable governance. In sports, if a whole team is having hard time winning, usually the players get a new coach. For example, the president of Hyatt Hotels shared with David HartleyLeonard of Newsweek (1987) that, "If there is anything I have learned in my 27 years in the service industry, it is this: 99 percent of all employees want to do a good job. How they perform is simply a reflection of the one for whom they work."

Mindfully conscious leaders get extraordinary things done from the many ordinary employees in their enterprises. At a very basic level, leadership is about influencing others and getting followers who believe in you (Maxwell, 1993). Adolph Hitler, Mahatma Gandhi, Martin Luther King Jr., and John F. Kennedy influenced many other individuals in significant ways. Millions of people were influenced by John F. Kennedy when he created Peace Corps., or led
America's space efforts with his creative goal to have a man land on the moon before the end of the 1960s.

All of us influence others. And, many others influence each one of us. Everyone, including the most introverts, influence thousands of others during their life time. A mother influences her growing children. A child may influence other children in school. A server influences customers in what they choose to eat. Many times, we do not fully realize how we influence others, or how we are influenced by others.

Different leaders influence their employees with different orientations and mindsets (Maxwell, 1993). These can be classified and clustered as listed below. For each level, more mindful leaders can provide a more meaningful motivation to their followers.

Level-I Position Oriented Leader,

Level-2 Partnership Oriented Leader,

Level-3 Production Task Oriented Leader,

Level-4 People's Development Oriented Leader, and

Level-5 Personhood Oriented Mindful Leader.

\section{Level-I Position Oriented Leader}

The Position-oriented leader's influence comes with the formal legitimate position the leader has in an enterprise (Maxwell, 1993). The leaders who rely exclusively on their positional power have only temporary influence on others. The moment the Positional leader loses the appointed position of authority, the influence starts waning and it disappears very soon. The security of the Positional leaders is based primarily on their official titles, and not on the leadership talent of the individuals. Positional leaders often influence their followers by intimidation and fear.

Most employees, on the other hand, are motivated by more mindful leaders who make them feel valued and competent (Minter, 201I). Leaders who give excessive negative feedback, that is mostly corrective, undermine these important sources of motivations. Their followers stop thinking creatively outside the box. They are not likely to think of creative new ideas, when they are all the time getting kicked in the gut by their leaders. Even the most motivated employees would decline their engagement with constant negative feedback. More mindful leaders, on the other hand, reinforce good behavior through positive feedback. They are mindful of their followers' changing needs. 


\section{Level-2 Partnership-Oriented Leader}

The second-level Partnership-oriented leader influences others by cultivating inter-relationships (Maxwell, 1993). The Partnership-oriented leaders invest significant time, energy, and efforts on meeting others' needs and desires. This builds strong sustaining relationships. The atmosphere is that of socializing at a country club. Followers love their Partnership-oriented leaders, because they simply like to follow these leaders.

A common trap for such relationship oriented leaders is to spend a lot of their time and efforts on 'problem children' employees. The well-performing members get neglected, and they may get de-motivated. Some higherperforming employees may, therefore, intentionally lower their performance or productivity to draw more attention from their leaders (Minter, 20II).

Most enterprises and leaders push for using teams of multiple individuals to solve their challenging problems demanding creative solutions. But very few of these teams turn into communities of interdependent individuals. True communities developed by more mindful leaders offer a continuous stream of genuine feedback and praise to their members. They develop a healthy 'bullshit meter' that filters out false sugar-coated compliments and unproductive criticisms. There is a lively intensity and respectfor creativity, honesty, and fun (Klein and lzzo, 1998).

\section{Level-3 Production-Oriented Leader}

The third-level Production-oriented leader focuses on influencing the tasks confronting them, and meeting their production goals (Maxwell, 1993). Their followers are influenced periodically, and their needs and desires are met to produce certain outcomes or results. The followers admire their Production-oriented leader for what the leader has done and accomplished for their organization.

These production-oriented leaders, if mindful, would like to make their contributions - preferably something larger than meeting just their immediate physical or materialistic needs. Working as a means to meet petty self-centered materialistic ends, such as pay, power, or pension, misses the potentially more profound value that our work can produce. Our inner souls desire a purpose that goes beyond mere surviving physically. Often the people with the most talent and aspirations tend to have a higher need to make contributions to their enterprises. They want to see the difference that their efforts produce.
Many leaders and enterprises offer their employees the wrong incentives - to meet their petty low-level survival and materialistic needs. These include a bigger car, a larger corner office, or vacations only for themselves and their families. What about offering the employees the right higher-level incentives - to provide an opportunity to make a significant contribution to their communities or make a big difference to the welfare and growth of their society?

Few leaders and fewer enterprises fully tap the energy and passion of followers with a keenness to make bigger contributions (Klein and Izzo, 1998). Many production oriented leaders wonder why their people don't work harder. Instead of demanding hard work by threatening employees' survival at the lowest level of Maslow's hierarchy of needs, more leaders could tap into higher level needs of their employees to motivate them. Motivating the followers to make significant contributions would produce more sustained hard work, and higher quality output from the followers. Promoting ecologically sustainable production operations could be such more meaningful motivation.

Many Production-Oriented leaders often follow the old adage that a good leader never asks someone else to do something that they themselves have never done before. Some leaders get so busy with the demands of high-level strategic leadership that they lose touch with their core business operations at the ground level. This reduces engagement and loyalty of the very people who are executing and implementing the strategic plans formulated by the leader. Without the people's support, every accomplishment can come to a halt (Minter, 20II).

But, the Production-Oriented leaders must also learn to delegate. According to the University of Tennessee's Professor Michael Mclntyre, leaders do not delegate for three major reasons (Minter, 20II). First, some leaders crave control and predictable performance - so they tend to do themselves all they can do. Second, some leaders like to demonstrate their own expertise and competencies. And finally, some leaders don't know how to delegate tasks or responsibilities.

However, with the growing economic pressures and rising expectations of stakeholders from their leaders, many leaders may start seeing their workers as just functional cogs in a complex socio-techno-economic machine. When Production-oriented leaders turn people into things, these leaders take away the employees' ability to creatively contribute and go above and beyond the leaders' 
expectations. Employees do best work when what they do is meaningful to them, and to their enterprises.

More mindful Production-oriented leaders can help employees see that they don't just work to make products or profits, but they work to create a difference in the lives of their customers. A higher purpose of our work is to help our society prosper and grow, to nurture our children to learn and thrive, and to improve the quality of our ageing people's quality of life. Thus, more mindful leaders can help turn work into something that benefits the society and nourishes everyone's soul (Klein and Izzo, 1998).

\section{Level-4 People's Development Oriented Leader}

The fourth-level People's Development-oriented leaders empower other individuals in order to generate consistently superior performance from them. This makes the followers loyal to their People Developing leaders. The People Developing leaders win their followers' hearts and sustained loyal commitments by helping the followers grow personally. The followers realize that they could not have grown as much by themselves, without the guidance of their mentoring leaders. The followers follow these leaders because of what these leaders have done for them.

Leaders, however, must not take for granted as if they own their employees. Leaders have to keep renewing their vows emotionally to re-energize their relationships with their employees. Leaders, from time to time, must remind their employees what fun it is to create new opportunities and remarkably change the world.

More mindful People Developing leaders listen intently to the true soul hiding within each individual. When a mindful leader listens intently to a person, the person feels valued. Leaders with poor listening skills cause alienation and separateness in their followers. Listening produces a sense of interdependence and shared commitment in a community of individuals (Klein and Izzo, 1998).

\section{Level-5 Personhood Oriented Mindful Leader}

The final fifth-level Personhood-oriented Mindful leaders influence other individuals because they respect the person their followers truly are, and what the followers represent authentically. These highly mindful leaders have referent power over their follower employees. Naturally, such mindful leaders may have to spend many years developing their relationships based on helping other people around them grow.

Many individual employees have an artificial character or a mask that they wear most of the times at work. When enterprises face crises or competitive challenges causing severe stress, often these masks come off and the true angry or frustrated individuals peek from underneath the masks. To solicit sustainable energies from their employees, more mindfully creative leaders must look for their followers' authentic inner cores (Klein and lzzo, 1998).

There are many enterprises where a large number of employees are not allowed to connect with or express their inner authentic core. Mindfully creative leaders can help people awaken their true passions and make significant contributions to their enterprise and to their community. These highly mindful leaders encourage their employees to seek a fit between their authentic self and their dayto-day work. Individuals are likely to be most committed when their work helps them fully express who they truly are. This generates their long-lasting fuller commitments.

By helping people discover and connect with their true Personhood, highly mindful leaders can help unearth their followers' higher values. These mindful leaders can foster self discovery in their people, and help unearth their untapped reservoirs of creative energy. Their work can pose their life question "Who am I?" Is our work a truthful expression of our authentic personhood, or is it a sellout? (Klein and Izzo, 1998)."

Instead of trying to fit together their conflicting expectations from their unfulfilling work and their very different personal passions, the employees working with more mindful leaders can breathe more harmoniously when their authentic cores are aligned with their work. Many employees, as well as their less mindful leaders at the previous four levels, are too busy perfecting their performances, as expected by others above them, instead of listening to their inner voices or trying to meet 
their own higher-level needs. More mindful leaders can drastically change all that, and they can tremendously boost their followers' individual and collective creativity.

\section{Selected Managerial and Educational Implications of More Mindful Leaders}

There are a number of complex challenges facing mankind where the more mindful leaders and creative individuals can make significant creative impact using the concepts outlined in this research study.

If the mankind is to survive the impending climate crisis, we would urgently need the fullest engagement of all the willing creative people that we can get to help and collectively create our sustainable solutions.

The rapidly rising health care costs are severely undermining the quality of life of most Americans in the 2 Ist century. More mindful leaders and their creative individual followers can help identify new opportunities and more innovative products and technologies to alleviate our seemingly un-surmountable pains.

Finally, alleviating chronic poverty in certain parts of the world demands innovative collective solutions by all. More mindful leaders can empathize and inspire their individual followers to innovate creative low-cost, high-value, and fast-delivery solutions.

All these global challenges demand that more mindful leaders nourish and permit higher levels of creativity in as many individuals as possible.

If our enterprises demand and require increasingly mindful leaders and creative individuals, then we must start bringing about a proactive change in our educational curricula to help young and not so young students become more mindful and creative. Awakening our creative and critical thinking and providing experiential development opportunities are some of the first steps that our universities and learning institutions can make. These and other related practices to promote mindfulness and creativity will be the focus of a series of subsequent research studies.

\section{About the Author}

Since 1997, Dr. R. Ray Gehani has been the Founder-Director of the Graduate Programs in Technology Management and Innovation at the University of Akron. Formerly, as the Chairman of College of Innovation Management and Entrepreneurship (COLIME) of TIMS/ORSA that he merged with other professional Colleges, and helped establish the Technology Management Section of the Institute for Operations Research and Management Science (INFORMS) in 1997. In 1998, he solo-authored a seminal book on Technology Management and Operations (John Wiley \& Sons). He has published more than 30 articles on innovation in leading journals.

\section{References}

AMABILE, Teresa and Khaire, Mukti (2008). Creativity and the Role of the Leader. Harvard Business Review, Oct., 100-109.

AMABILE, Teresa M. (1997). Motivating Creativity in Organizations: On Doing What You Love and Loving What You Do. California Management Review, 40(I), 39-58.

AMABILE, T. M. (1996). Creativity in Context: Update to the Social Psychology of Creativity. Boulder, CO, Westview Press.

AMABILE, T. M. (1983). The Social Psychology of Creativity. New York city, Springer Verlag.

ARENDT, Lucy A. (2009). Transformational leadership and follower creativity: The moderating effect of leader humor. Review of Business Research. 9(4), 100-106.

BROWN, R.T. (1989). Creativity: What are we to measure? In J.A. Glover, R.R. Ronning, and C. R. Reynolds (Eds.), Handbook of Creativity. New York, Plenum.

CSIKSENTMIHALYI, Mihaly. (1996). Creativity: Flow and Psychology of Discovery and Invention. New York, HarperCollins.

CSIKSENTMIHALYI, Mihaly. (1990). Flow: The Psychology of Optimal Experience. New York, Harper \& Row. 
GARDNER, H. (1993). Creating Minds: An Anatomy of Creativity Seen Through the Lives of Freud, Einstein, Picasso, Einstein, Stravinsky, Eliot, Graham, and Gandhi. New York, Basic Books.

GEHANI, R. Ray. (20Ilc). Be Fearlessly Creative with Mindful Meditation. The Lotus, June, 9. Accessible at www.fica-cleeland/lotus.

GEHANI, R. Ray. (20llb). Wanted: A More Creative Mind. The Lotus, May, 9. Accessible at www.fica-cleeland/lotus.

GEHANI, R. Ray. (20lla). Let us be Mindful of Turning Leaves. The Lotus, March, 9. Accessible at www.ficacleeland/lotus.

GEHANI, R. Ray. (20I0). Innovation and Enterprise. Rochester, NY, Global Vision Publishers.

GEHANI, R. Ray. (1998). Management of Technology and Operations. New York: John Wiley \& Sons.

GETZELS,J.W.(1975).Problemfindingand theinventiveness of solutions. Journal of Creative Behavior, 9, 12-18.

GETZELS, J. W. and Csiksentmihalyi, Mihaly. (1976). The Creative Vision: A Longitudinal Study of Problem Finding in Art. New York: Wiley.

GOLANN, S. E. (1963). Psychological study of Creativity. Psychological Bulletin, 60, 548-565.

GREENLEAF, Robert. (1977). Servant Leadership: A Journey into the Nature of Legitimate Power and Greatness. New York, Paulist Press.

GUILFORD, J. P. (1968). Creativity, Intelligence, and Their educational Implications. San Diego, CA: Edits/Knapp.

HARTLEY-LEONARD, David. (1987). Perspectives, Newsweek, 24 August, II.

JAWORSKY, Joseph. (1996). Synchronicity The Inner Path of Leadership. San Francisco, Barrett-Koehler.

KLEIN, Eric and Izzo, John B. (1998). Awakening Corporate Soul: Four Paths to Unleash the Power of People at Work. San Diego, Fairwinds Press.
LAVIN, Audrey and Gehani, R. Ray. (20II). Turning Leaves. Canton, $\mathrm{OH}, \mathrm{WWW}$ Creative Publishers.

MAXWELL, John C. (1993). Developing the Leader Within You. Nashville, Thomas Nelson Publishers.

MINTER, Steve. (20II). I0 Management Traps - and How to Avoid Them. IndustryWeek, Spring, 26-28.

MUMFORD, M. D. and Gustafson, S.B. (200I). Creative thought: Cognition and problem solving in dynamic systems. In M. Runco (Ed.), Creativity Research Handbook, Creskill, NY, Hampton.

NEWELL, A. and Simon, H. (1972). Human Problem Solving. Englewood Cliffs, NJ, Prentice Hall.

RUNCO, M.A. and Sakamoto, S.O. (1999). Experimental study of creativity. In R.J. Sternberg (Ed.), The Nature of Creativity, New York, Cambridge University Press.

SENGE, Peter. 1996. Preface. In Jaworsky, Joseph. (1996). Synchronicity The Inner Path of Leadership. San Francisco, Barrett-Koehler.

SENGE, Pater. (1990). The Fifth Discipline, New York, Doubleday.

SMITH, Deborah K., Paradice, David B. and Smith, Steven M. (2000). Prepare Your Mind for Creativity. Communications of the ACM, 43(7), III-116.

STENBERG, R. J., and Lubart, T. I. (1995). Defying the Crowd: Cultivating Creativity in a Culture of Conformity. New York, Free Press.

VINCENT, A.S., Decker, B.P., and Mumford, M.D. (2002). Divergent thinking, intelligence, and expertise: $A$ test of alternative modes. Creativity Research Journal, I4, I63-178.

WEISBERG, R.W. (1999). Creativity and Intelligence. In R. J. Sternberg (Ed.), The Nature of Creativity. New York: Cambridge University Press. 
J. Technol. Manag. Innov. 20I I,Volume 6, Issue 3 